\title{
Ethnobotanical uses and socio-economic importance of climbing species in Arunachal Pradesh, India
}

\author{
Soyala Kashung, Padma Raj Gajurel* \& Binay Singh \\ Forest Systematic and Horticulture Laboratory, Department of Forestry, North Eastern Regional Institute of Sciences and Technology, Nirjuli \\ 791 109, Arunachal Pradesh, India \\ *Email: prgajurel@gmail.com
}

\section{ARTICLE HISTORY}

Received: 11 March 2020

Accepted: 18 April 2020

Published: 01 July 2020

\section{KEYWORDS}

Papum Pare district

climbing species

diversity

ethnobotanical uses

medicine

nutrition

\begin{abstract}
The species diversity of climber is found very high in the tropical region of the world. The tropical and sub tropical forests in the Eastern Himalayan state exhibit a good representation of climbing flora. A study on the taxonomic diversity and socio economic importance of climbing plants occurring in Papum Pare district, Arunachal Pradesh was carried out. A total of 187 climbing species were recorded amongst which 61 species distributed over 43 genera and 20 families are found having various economic applications. The detailed ethnobotanical uses and economic importance of all the species were evaluated and presented. Based on their end use, the species are grouped under six broad categories where the highest number of 29 species are found used as local medicines. Additionally, 22 other species were used as wild edibles, 7 species as construction and handicraft materials and 7 species for hunting and fishing. Among all, the species like Piper longum, Abrus precatorius, Calamus tenuis, Dioscorea spp. and Rubia cordifolia have good commercial and economic values. The study revealed that the climbing species are linked with the livelihood as well as for the socio economic support to the local communities. As the majority of the species are used for medicines, fruits and vegetables, the climbing species are found to be playing a vital role in the fulfilment of the medicinal and nutritional requirements of the local people.
\end{abstract}

\section{Introduction}

The climbing plants are found ecologically and economically one of the important floristic elements, particularly in tropical and subtropical regions. However, the climbing species are most understudied among the various habit forms and their studies are more or less neglected by the majority of the researchers (1). Studies on the climbing plants worldwide are often clumped together with plants of all growth forms and often fail to highlight the various contributions (2). Climbing plants are usually considered a nuisance by foresters and are generally cut down in any silviculturally managed forests (1). About $50 \%$ of the families of vascular plants contain climbing plants (3). They occur in all forest ecosystems with its highest occurrence in tropical and sub-tropical forests $(4,5)$. Globally, studies on the climbing species are focussed primarily on lianas occurring in tropical forest communities by most of the researchers (6-8).
As compared to the lianas, studies on vines are relatively less and only a few researchers include vines in their studies $(9,10)$.

Climbing plants play very crucial roles in the forest communities and ecosystem dynamics $(11,12)$. Besides providing a canopy to canopy access for arboreal animals, these species provide important food materials for many other animals at the times of food scarcity with their abundant leaves as well as fruits and flowers (13). Many climbing plants are also widely used by the people especially those living in rural areas as an important source of food, medicine and edible fruits $(4,14)$. Apart from food and medicine, many climbing plants are important sources of non-timber forest products (NTFPs) used for different domestic purposes including furniture, fuelwood, rope making etc. $(7,15)$.

The Eastern Himalayan state of Arunachal Pradesh exhibits rich diversity of flowering plants

(c) Kashung et al. (2020). This is an open-access article distributed under the terms of the Creative Commons Attribution License, which permits unrestricted use, distribution and reproduction in any medium, provided the original author and source are credited (https://creativecommons.org/licenses/by/4.0/).

To cite this article: Kashung S, Gajurel P R, Singh B. Ethnobotanical uses and socio-economic importance of climbing species in Arunachal Pradesh, India. Plant Science Today. 2020;7(3):371-377. https://doi.org/10.14719/pst.2020.7.3.771 
with the occurrence of more than 5000 species of flowering plants (16). The tropical and subtropical forests of the state particularly below $1500 \mathrm{~m}$ altitude are found suitable habitats for various climbing species viz. lianas and herbaceous vines. The state is inhabited by 26 major tribes and 110 sub-tribes with each tribe having their own sociocultural practices and traditions (17). The tribal people, apart from utilising the local plant resources for their nutrient supplement, also depend largely on forest resources for generating additional income which in turn improves their socio-economic condition. Many of the products obtained from the forest are often seen on sale in the local markets. To understand the taxonomic diversity and economic values of climbing plants a study was conducted selecting the district Papum Pare. The district represents suitable habitats for different climbing species as both the tropical and subtropical climate is prevalent in the area. Moreover, the state capital city Itanagar lies in the district and hence habitat degradation is assumed to be very high because of rapid developmental activities.

\section{Study site}

The Papum Pare district of Arunachal Pradesh lies on the foothills of Himalaya and located between $26^{\circ} 56$ ' $11^{\prime \prime}$ to $27^{\circ} 35^{\prime} 44^{\prime \prime}$ North latitude and $93^{\circ} 12^{\prime} 45^{\prime \prime}$ to $94^{\circ} 13^{\prime} 30^{\prime \prime}$ East longitude. The district covers a geographical area of $3462 \mathrm{~km}^{2}$ and is bounded in the North by Lower Subansiri district, West by East Kameng district, East by West Siang district and South by North Lakhimpur district of Assam (Fig. 1).
As the state is uniquely situated in the transition zone between the Himalayan and Indo-Burmese regions, a major part of the Papum Pare district is covered by thick forest mostly with the humid tropical and subtropical type of vegetation. The forest areas are rich in diversified floras, where the climbers form an important component both in normal and degraded forests. The district is dominantly inhabited by the Nyishi tribe belonging to the Indo-Mongoloid group of people. The district is also home to numerous tribal population which utilizes a wide variety of forest resources for sustenance and livelihood (18).

\section{Materials and Methods}

The present study is the outcome of extensive periodical field surveys undertaken from 2015 to 2018 to different parts of Papum Pare district of Arunachal Pradesh. The collected species were identified using various taxonomic literatures (19-22) and consultation with regional herbaria (ASSAM, ARUN). All the specimens were processed into mounted herbarium sheets as per the conventional methods of drying, poisoning, mounting and labelling (23). The processed herbarium specimens have been deposited in the herbarium of the Department of Forestry, North Eastern Regional Institute of Science \& Technology (NERIST), Nirjuli, Arunachal Pradesh, India. Information on the various uses of the climbing plants of the district was obtained through in-forest interviews and interaction with the local people as well as local market surveys using modified

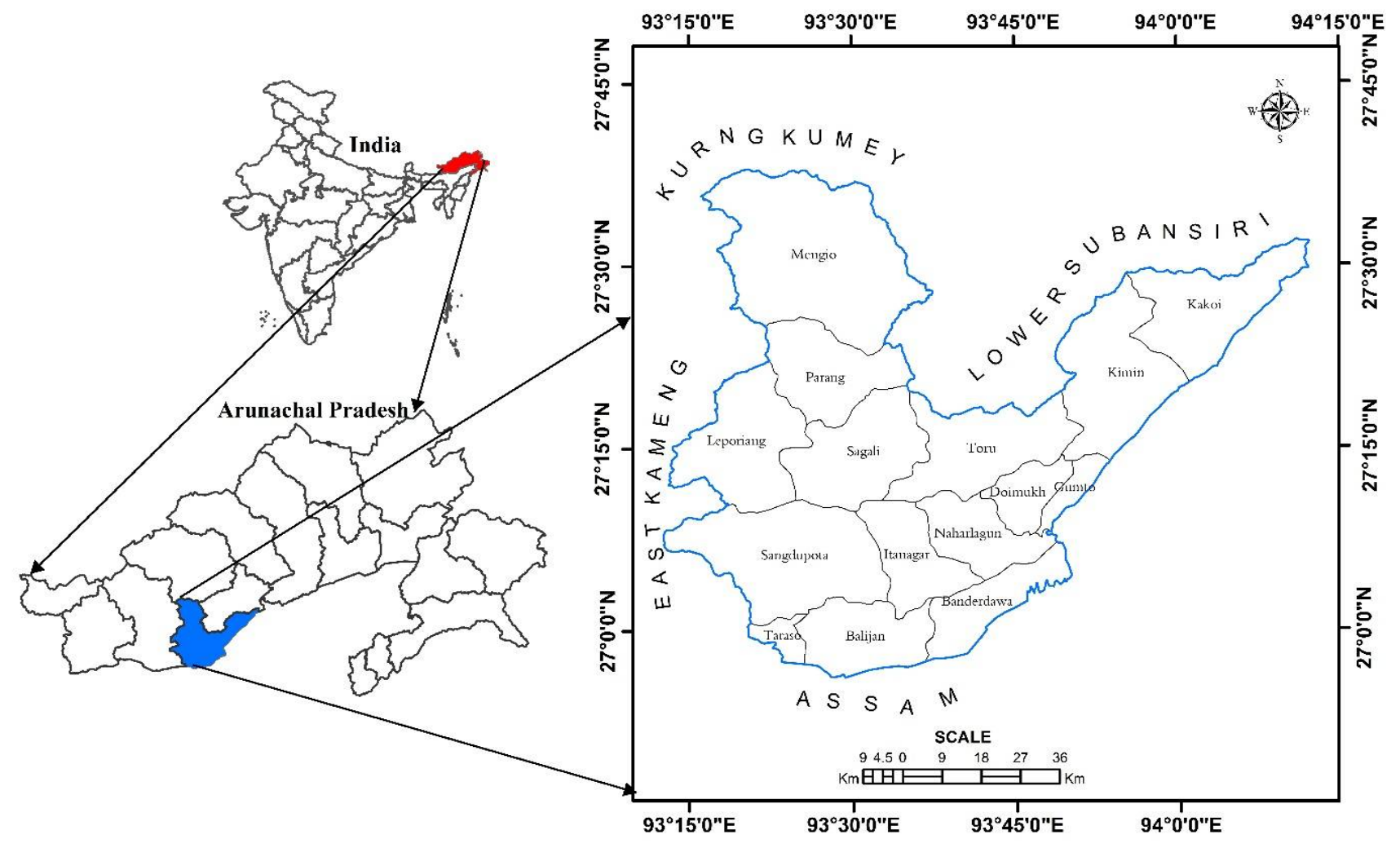

Fig. 1. Map of the study site. 
semi-structured questionnaires through ethnobotanical approaches (24). The data on each of the plant species for their local uses, mode of usage and parts used were collected. The socio-economic values of all the species were analysed based on their ethnobotanical and economic importance.

\section{Results and Discussion}

The present study revealed the rich floristic diversity of the useful climbing plant resources of Papum Pare district of Arunachal Pradesh. A total of 187 species were collected and identified. Among these, 61 climbing species having different economic uses were recorded. All the species belong to Dicotyledons and Monocotyledon groups comprising 48 and 13 species respectively. The species are spread over 43 genera under 20 families. Among the families, Fabaceae has the highest number representation comprising 9 species followed by Cucurbitaceae with 8 species and Rosaceae with 7 species. In terms of genera, Rubus ranks the highest with 6 species and Dioscorea with 4 species. Among the various plant parts used, the most commonly used part is leaves (25 spp.), followed by fruits (18 spp.), stem (12 spp.) and the least is bark (2 spp.) (Fig. 2). The list of all the recorded species with their family, habit, part(s) used, mode of uses and market prices is presented

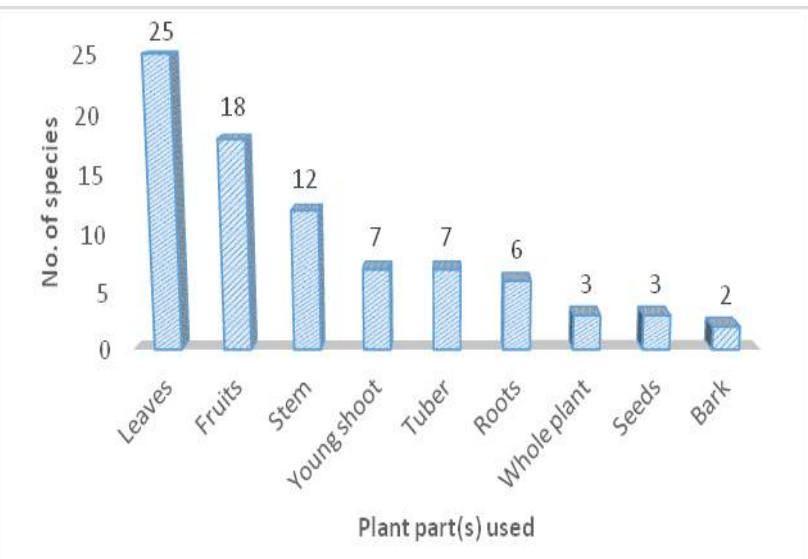

Fig. 2. Number of climbing species with various plant part(s) used.

alphabetically in Supplementary Table 1.

Analysis on the climbing mechanisms revealed the twining climbers as the highest group with 24 taxa (39.34 \%) followed by scrambler 13 species (21.31\%), tendril climber 10 species (16.39\%), root climber 9 species (14.75\%) and least representation by Rambler with 5 species (8.2 \%) (Fig. 3).

All the species based on their end uses are grouped into 6 (six) categories as medicines, wild edible, construction and handicraft materials, intoxicants/narcotics, fishing and hunting (as baits, poison, making bows) and dyes. Of the total 61 species recorded, 29 species are used in preparing local medicine, 22 species as wild edibles, 7 species for construction and handicraft materials, 2 species as intoxicants/narcotics, 7 species for fishing and hunting and 1 species for dyeing (colorant) (Fig. 4). Some of the species are included in more than one

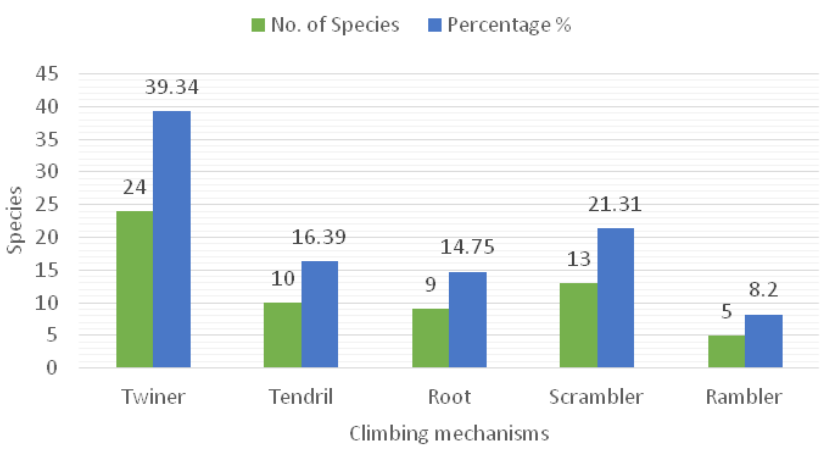

Fig. 3. Habit and climbing mechanisms.

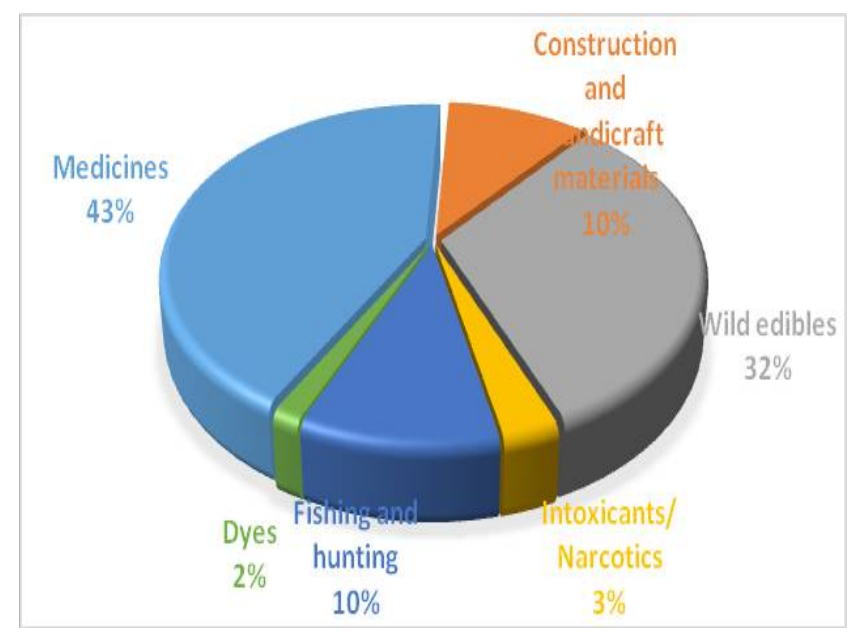

Fig. 4. Percentage of climbing species in different use categories.

category in the way that they are used for more than one purpose like Calamus flagellum, Dioscorea bulbifera, Lagenaria siceraria, Mastersia assamica, etc. Majority of these plants are collected directly from the adjacent forest areas. Only a few plants like Abrus precatorius, Calamus tenuis, Dioscorea alata, Ipomoea batatas, Momordica charantia etc. are collected both from wild and cultivation.

Among the 29 medicinal plants, 14 species like Caesalpinia cucullata, Dioscorea bulbifera, Hedyotis scandens, Mastersia assamica, Paederia foetida, Piper betleoides, P. longum, Stephania glandulifera, Tinospora cordifolia etc. are found to be used in treating multiple ailments. Report of similar usage of species like Paedaria foetida, Stephania glandulifera, Tinospora cordifolia, Mastersia assamica, Piper longum, Abrus precatorius, Rubia cordifolia, Holboellia latifolia, etc. were also recorded by some workers from the state (25-27). Some of the medicinal plants like Abrus precatorius, Piper longum, Stephania japonica, Tinospora cordifolia etc. are also included in the Indian System of Medicine for their high medicinal application and thus their systematic collection should be encouraged. The wild edibles consist of ten vegetable plants and twelve edible fruit species. The species like Actinidia callosa, Holboellia latifolia, Calamus flagellum, Rubus ellipticus, Rubus lucens, Toddalia asiatica etc. are preferred to their edible fruits which are taken either raw or after ripening. While the species namely Dioscorea alata, D. esculenta, Momordica dioica, Luffa cylindrica, Vigna umbellata etc. are used mostly for vegetables. Consumption of wild vegetables as a 

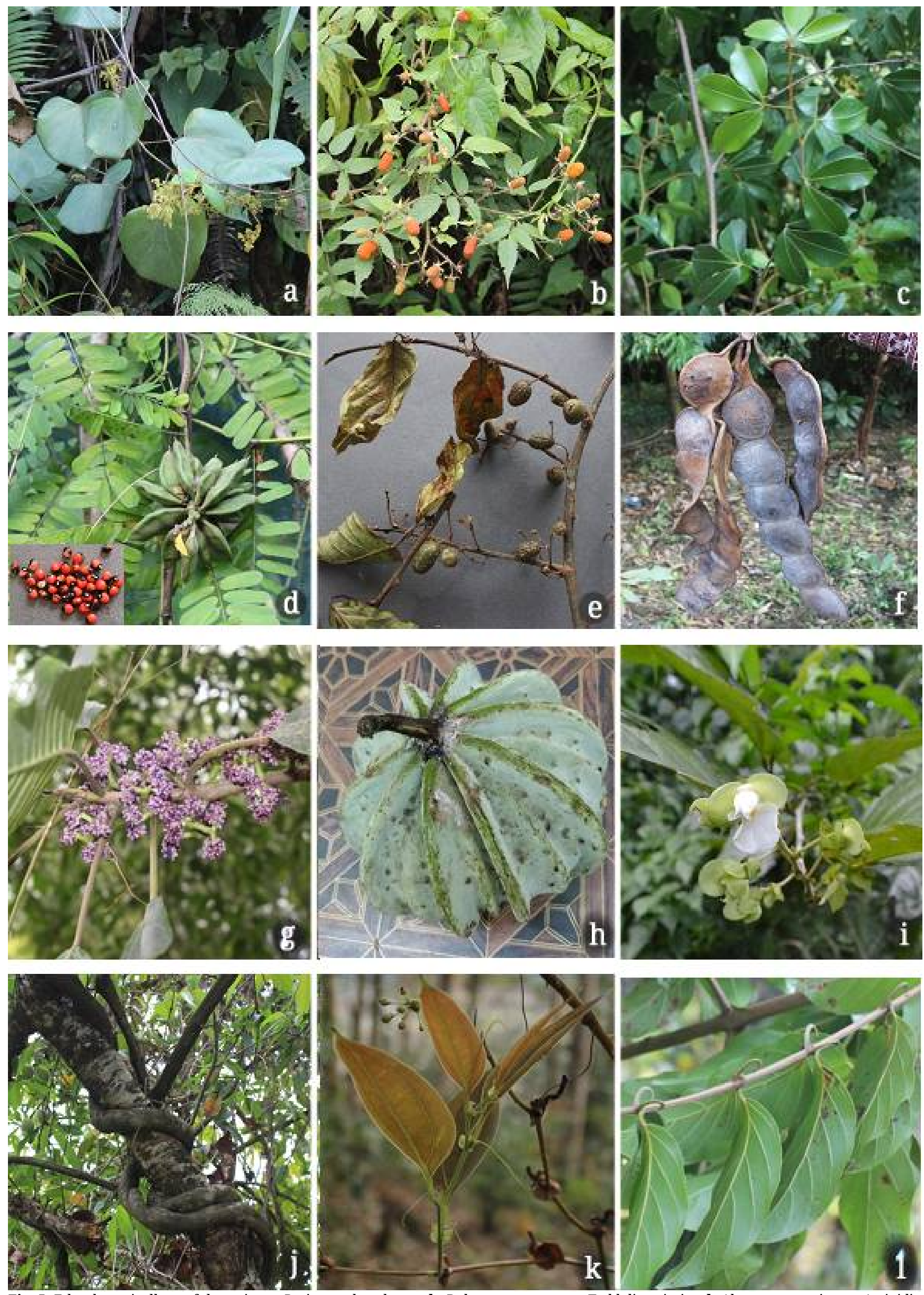

Fig. 5. Ethnobotanically useful species a. Pericampylus glaucus b. Rubus sumatranus c. Toddalia asiatica d. Abrus precatorius e. Actinidia callosa f. Entada phaseoloides g. Poikilospermum naucleiflorum h. Hodgsonia heteroclita i. Dalhousiea bracteata j. Croton caudatus k. Smilax perfoliata l. Uncaria sessilifructus. 

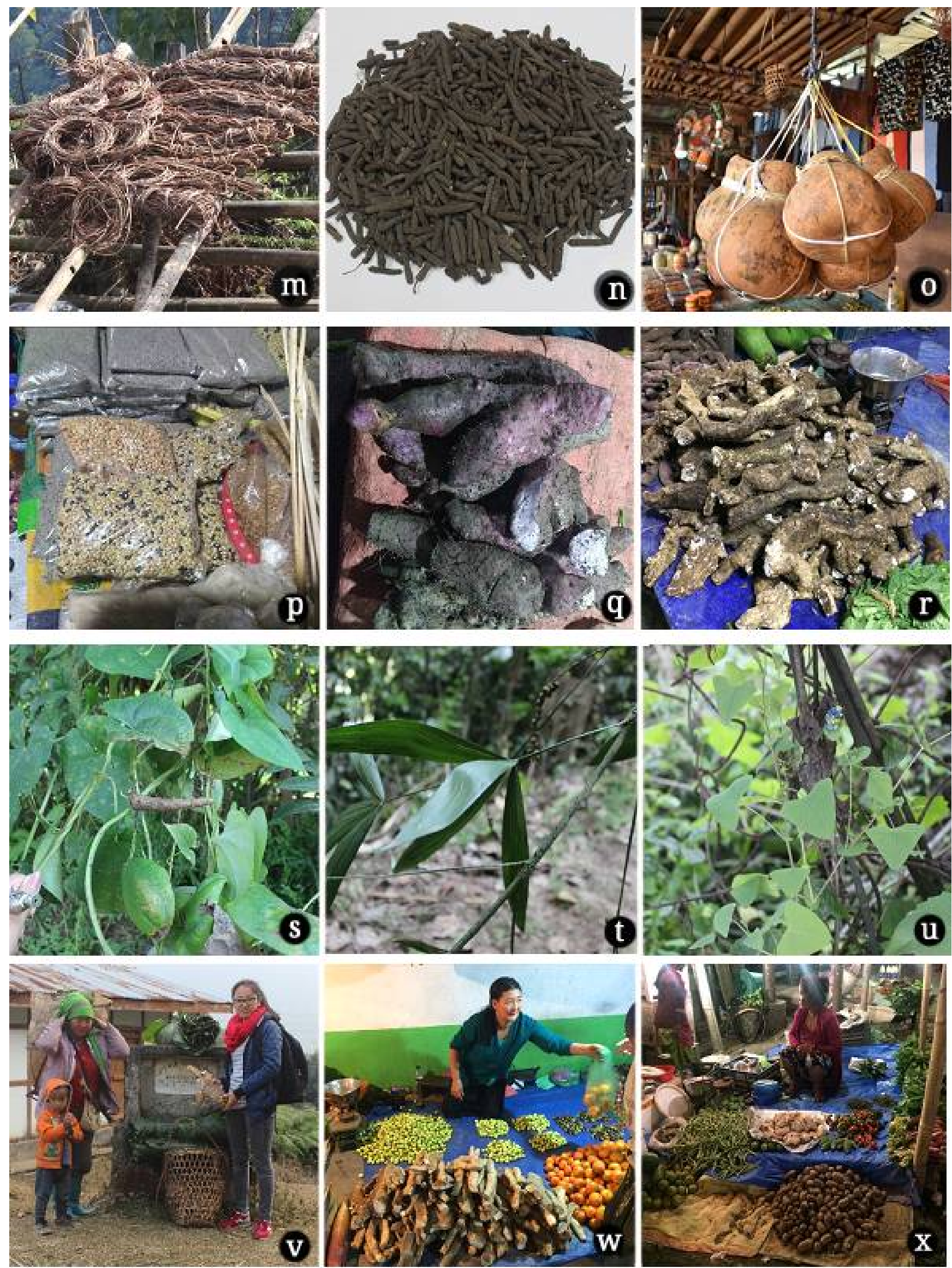

Fig. 6. Socio economically important climbing species. m. Stem of Rubia cordifolia $\mathbf{n}$. fruit of Piper longum $\mathbf{o}$. fruit of Lagenaria siceraria as container $\mathbf{p}$. seeds of Vigna umbellata q-r. rhizome of Dioscorea spp s. Dioscorea alata t. Calamus flagellum $\mathbf{u}$. Polygonum perfoliatum v. rhizome of Dioscorea spp. collected for sale $\mathbf{w} \& \mathbf{x}$. products in local markets.

traditional practice is common among tribes of north east India (28). Besides the medicinal and edible uses species like Calamus flagellum, Calamus tenuis,
Mastersia assamica, Pericampylus glaucus etc. are commonly preferred for house construction and handicraft materials as they are durable, strong and 
readily available. Three species of canes viz. Calamus flagellum, C. leptospadix and $C$. tenuis and its products are indispensable materials for rural communities because of their versatile utility. The contribution of canes and its products is not only subsistence oriented, in addition, they also collect and sell their products which are an important source of income for the locals. Amongst the seven species used for fishing and hunting, Acacia pennata, Anamirta cocculus and Millettia pachycarpa are used as fish poisons for easy catch which paralysed the fish. There is no report of untoward harm to the locals who consume the fish. However, phytochemical experimentations are yet to be evaluated for the toxicity of the said plants. The whole plant use of Acacia pennata as fish poison is also reported among the Adi tribe of Arunachal Pradesh (29). The present report of the use of fruits of Rhaphidophora decursiva and Tetrastigma serrulatum as bait for fish may be encouraged for sustainable fishing as they are environment friendly.

Reports of similar usage of many of the species were also recorded previously by various workers (30-32). However, medicinal uses of Argyreia nervosa, Pothos longipes and Uncaria sessilifructus; edible fruits of Toddalia asiatica, Rubus sumatranus etc.; Poikilospermum naucleiflorum for smoking; Mastersia assamica for its fibre use as thread of fishing nets; Pericampylus glaucus as tying material in house construction; Rhaphidophora lancifolia for fiber in bowstring are some of the unique used reported in the present study.

Besides meeting the nutritional requirement, the forest resources are also found supportive to fulfil the socio economic need of the locals to a considerable extent. Some of these species are also sold as vegetable in the local markets which in turn generate additional income. Species of Dioscorea, Ipomoea, Vigna etc. have a higher demand in the local markets. The market survey on the locally available species revealed that 14 of the species like Piper longum, Dioscorea bulbifera, D. alata, D. esculenta, Rubia cordifolia, Vigna umbellata, Calamus tenuis etc. are sold in the markets through collections from different forest areas as well as from cultivation sometimes. The prices of Dioscorea spp. in the local market ranges from Rs. $80 / \mathrm{Kg}$ (D. bulbifera) to Rs. 200/ $\mathrm{Kg}$ (D. alata). The secondary information collected from various sources revealed that eleven species namely Abrus precatorius, Anamirta cocculus, Argyreia nervosa, Asparagus racemosus, Calamus tenuis, C. flagellum, Dioscorea alata, D. bulbifera, Piper longum, Rubia cordifolia and Tinospora sinensis are found as commercially potential ones as the industrial demand of these species is very high. These species are also traded frequently in different parts of the world to meet commercial demand.

\section{Conclusion}

The present study shows the occurrence of various useful climbing plant resources including some high socio-economically important species. The results of the present study showed that forest resources continue to play a crucial role in the daily livelihood of the community, particularly in the health care system. Species like Hedyotis scandens, Padaeria foetida, Trichosanthes tricuspidata, Stephania glandulifera and Solena heterophylla which has multiple medicinal values can be further investigated for the active principles and tested for pharmacological trials for the human welfare. Overexploitation of the climbing species particularly the collection of roots and underground parts causes great damages leading to a gradual decrease in the population of the plants. Papum pare being the capital city of the district, many forest areas are degrading at a faster rate for various developmental activities which in turn become threats to the population of the wild forest resources. Therefore, there is a need to create awareness among the local people for the conservation of these plants to ensure their continued existence in the long run.

\section{Acknowledgements}

The authors are thankful to the local people of the study area for their cooperation and sharing their valuable knowledge on the traditional uses of climbing plants of the study area. We thank the forest officials and staff of various forest divisions for their help during the field work. We thank the scientist and officials of the herbarium of Botanical Survey of India, Shillong (ASSAM) and Arunachal Field Station, Itanagar (ARUN) for herbarium facilities. We also express our gratitude to the Director, NERIST and Head of Department, Forestry for providing all necessary facilities.

\section{Authors' contributions}

PRG and BS designed the objectives and plan of work. SK carried out the field work, analysed the data and wrote the manuscript. PRG and BS helped in data analysis, interpretation and manuscript correction.

\section{Conflict of interest}

The authors declare no conflict of interest.

\section{Supplementary file}

Table 1

\section{References}

1. Sarvalingam A, Rajendran A. Climbing Plants of the Southern Western Ghats of Coimbatore in India and Their Economic Uses. American-Eurasian Journal of Agricultural and Environmental Sciences. 2015;15(7):1312-22. https://www.idosi.org/aejaes/jaes15(7)15/14.pdf

2. Eilu G, Bukenya-Ziraba R. Local use of climbing plants of Budongo Forest Reserve, Western Uganda. Journal of Ethnobiology. 2004;24(2):307-27

3. Putz FE. The natural history of lianas on Barro Colorado Island, Panama. Ecology. 1984;65:1713-24. https://doi.org/ $10.2307 / 1937767$

4. Bongers F, Parren MPE, Swaine MD, Traore D. Forest climbing plants of West Africa: Introduction. In: Bongers F, Parren, 
MPE, Traore, D. editors. Forest climbing plants of West Africa: Diversity, Ecology and Management. UK: CAB International; Wallingford; Oxfordshire; 2005;5-18. https://doi.org/ 10.1079/9780851999142.0005

5. Quigley MF, Platt WJ. Composition and structure of seasonally deciduous forests in the Americas. Ecological Monographs. 2003;73(1):87-106. 9615(2003)073[0087:CASOSD]2.0.CO;2

6. Khadanga SS, Muthumperumal C, Parthasarathy N. Changes in Liana diversity over a decade in Indian tropical dry evergreen forests. In: Tripathi SK, ed. Biodiversity in Tropical Ecosystems. New Delhi: Today and Tomorrow's Printers and Publishers. 2015;61-79

7. Schnitzer SA, Bongers F. The ecology of lianas and their role in forests. Trends in Ecology and Evolution. 2002;17:223-30. https://doi.org/10.1016/S0169-5347(02)02491-6

8. Naidu MT, Kumar OA, Venkaiah M. Taxonomic Diversity of Lianas in Tropical Forests of Northern Eastern Ghats of Andhra Pradesh, India. Notulae Scientia Biologicae. 2014;6(1):59-65. https://doi.org/10.15835/nsb619193

9. Gallagher RV, Leishman MR, Moles AT. Traits and ecological strategies of Australian tropical and temperate climbing plants. Journal of Biogeography. 2011;38:828-39. https://doi.org/10.1111/j.1365-2699.2010.02455.x

10. Singh V, Singh RK, Gupta SL. Diversity of climbers, trailers and parasitic plants in Botanical Garden, Botanical Survey of India, Central Regional Centre, Allahabad. Indian Journal of Forestry. 2015;38(2):195-200

11. Nabe-Nielsen J. Diversity and distribution of lianas in a neotropical rain forest, Yasuni National Park, Ecuador. Journal of Tropical Ecology. 2001;17(1):1-19. https://doi.org/10.1017/ S0266467401001018

12. Bongers F, Schnitzer SA, Traore D. The importance of lianas and consequences for forest management in West Africa. Bioterre. 2002;59-70

13. Putz FE, Windsor DM. Liana Phenology on Barro Colorado Island, Panama. Biotropica. 1987;19(4):334-41. https://doi.org/ $10.2307 / 2388631$

14. Muhwezi O, Cunningham AB, Bukenya-Ziraba R. Lianas and Livelihoods: The Role of Fibrous Forest Plants in Food Security and Society around Bwindi Impenetrable National Park Uganda. Economic Botany. 2009;63:340-52. https://doi.org/ 10.1007/s12231-009-9096-1

15. Putz FE, Mooney HA, editors. The Biology of vines. Cambridge University Press. 1991. https://doi.org/10.1017/ CBO9780511897658

16. Dash SS, Singh P. Flora of Kurung Kumey District Arunachal Pradesh. Kolkata: Botanical Survey of India. 2017

17. Arunachal Pradesh. Department of Planning. A Development Profile of Arunachal Pradesh [Internet]. Itanagar [cited on 2020 April 12]. Available from: http://www.arunachalplan.gov.in/html/docs/1_profile_arp.pdf
18. Arunachal Pradesh. Central Ground Water Board. Ground Water Information Booklet Papum Pare District, Arunachal Pradesh [Internet]. Guwahati: Ministry of Water Resources, North Eastern Region; 2012 [cited on 2020 April 12] Available from: http://cgwb.gov.in/District_Profile/Arunachal/ papum\%20pare.pdf

19. Hajra PK, Verma DM, Giri GS, ed. Materials for the Flora of Arunachal Pradesh. Vol 1. Calcutta: Botanical Survey of India. 1996

20. Giri GS, Pramanik A, Chowdhery HJ, ed. Materials for the Flora of Arunachal Pradesh. Vol. 2 \& 3. Calcutta: Botanical Survey of India: 2008-09

21. Hooker JD. The Flora of British India. Vol. 1-7. London: L. Reeve \& Co. 1875-97. https://doi.org/10.5962/bhl.title.678

22. Kanjilal UN, Kanjilal PC, Dey RN, Das A. Flora of Assam. Vol. 15. Meghalaya: Govt. Press. 1934-40

23. Jain SK, Rao RR. A Handbook of Field and Herbarium Methods. New Delhi: Today and Tomorrow's Publication. 1977

24. Jain SK, Mudgal V. A Hand book of Ethnobotany. Dehra Dun: Bishen Singh Mahendra Pal Singh. 1999

25. Singh AV, Asha H. Wild Edible Fruits of Arunachal Pradesh. International Journal of Innovative Research in Science, Engineering and Technology. 2017;6(6):12203-09. https://doi.org/ 10.15680/IJIRSET.2017.0606285

26. Srivastava RC, Nyishi Community. Traditional knowledge of Nyishi (Daffla) tribe of Arunachal Pradesh. Indian Journal of Traditional Knowledge. 2010;9(1):26-37

27. Khongsai M, Saikia SP, Kayang H. Ethnomedicinal plants used by different tribes of Arunachal Pradesh. Indian Journal of Traditional Knowledge. 2011;10(3):541-46

28. Panmei R, Gajurel PR, Singh B. Ethnobotany and nutritional values of some selected wild edible plants used by Rongmei tribe of Manipur northeast India. International journal of Applied Biology and Pharmaceutical technology. 2016;7(4):1-9. https://doi.org/10.21276/ijabpt.2016.7.4.1

29. Yumnam JY, Tripathi OP. Ethnobotany: Plants use in fishing and hunting by Adi tribe of Arunachal Pradesh. Indian Journal of Traditional Knowledge. 2013;12(1):157-61.

30. Saheb TS. A Study on Medicinal Climbers of Nallamalais, Andhra Pradesh. International Journal of Multidisciplinary Research and Development. 2014;1(5):172-76

31. Dutta B. Food and medicinal values of certain species of Dioscorea with special reference to Assam. Journal of Pharmacognosy and Phytochemistry. 2015;3(4):15-18

32. Singh AG, Kumar A. Ethnomedicinal aspects of climbing plants of Palpa district, Nepal. Tropical Plant Research. 2017;4(2):30713. https://doi.org/10.22271/tpr.2017.v4.i2.040 